Article

\title{
Eradication of Saccharomyces cerevisiae by Pulsed Electric Field Treatments
}

\author{
Efrat Emanuel ${ }^{1}$, Irina Dubrovin ${ }^{1}$, Ester Hanya ${ }^{1}$, Gad A. Pinhasi ${ }^{1}{ }^{\circledR}$, Roman Pogreb ${ }^{2}$ and \\ Rivka Cahan ${ }^{1, *}$ \\ 1 Department of Chemical Engineering and Biotechnology, Ariel University, Ariel 40700, Israel; \\ efiem80@gmail.com (E.E.); Irinadu@ariel.ac.il (I.D.); esterhanya@gmail.com (E.H.); gadip@ariel.ac.il (G.A.P.) \\ 2 Department of Physics, Ariel University, Ariel 40700, Israel; ptoman@ariel.ac.il \\ * Correspondence: rivkac@ariel.ac.il; Tel.: +972-54-7740293
}

Received: 4 September 2020; Accepted: 28 October 2020; Published: 29 October 2020

\begin{abstract}
One of the promising technologies that can inactivate microorganisms without heat is pulsed electric field (PEF) treatment. The aim of this study was to examine the influence of PEF treatment $\left(2.9 \mathrm{kV} \mathrm{cm}^{-1}, 100 \mathrm{~Hz}, 5000\right.$ pulses in trains mode of 500 pulses with a pulse duration of $10 \mu \mathrm{s})$ on Saccharomyces cerevisiae eradication and resealing in different conditions, such as current density (which is influenced by the medium conductivity), the sort of medium (phosphate buffered saline (PBS) vs. yeast malt broth (YMB) and a combined treatment of PEF with the addition of preservatives. When the S. cerevisiae were suspended in PBS, increasing the current density from 0.02 to $3.3 \mathrm{~A} \mathrm{~cm}^{-2}$ (corresponding to a total specific energy of 22.04 to $614.59 \mathrm{~kJ} \mathrm{~kg}^{-1}$ ) led to an increase of S. cerevisiae eradication. At $3.3 \mathrm{~A} \mathrm{~cm}^{-2}$, a total S. cerevisiae eradication was observed. However, when the S. cerevisiae in PBS was treated with the highest current density of $3.3 \mathrm{~A} \mathrm{~cm}^{-2}$, followed by dilution in a rich YMB medium, a phenomenon of cell membrane resealing was observed by flow cytometry (FCM) and CFU analysis. The viability of S. cerevisiae was also examined when the culture was exposed to repeating PEF treatments (up to four cycles) with and without the addition of preservatives. This experiment was performed when the S. cerevisiae were suspended in YMB containing tartaric acid (pH 3.4) and ethanol to a final concentration of $10 \%(v / v)$, which mimics wine. It was shown that one PEF treatment cycle led to a reduction of $1.35 \log 10$, compared to $2.24 \log 10$ when four cycles were applied. However, no synergic effect was observed when the preservatives, free $\mathrm{SO}_{2}$, and sorbic acid were added. This study shows the important and necessary knowledge about yeast eradication and membrane recovery processes after PEF treatment, in particular for application in the liquid food industry.
\end{abstract}

Keywords: pulsed electric fields; current density; conductivity; eradication; yeast

\section{Introduction}

Microorganism sterilization is an essential process in a variety of industries and medical applications. The available methods include thermal treatments, filtration, preservative addition, ultraviolet (UV) radiation, pulsed light (PL), cold plasma (CP), and pulsed electric fields (PEFs). Thermal treatments are the common method for inactivating microorganisms in the food industry, and there are comprehensive data on the available thermal processes [1]. However, a variety of food products are damaged, and their quality is decreased by exposure to thermal treatments. Wine is an example of a food product in which quality is impaired when sterilized by thermal treatments.

PEF is a promising technology that can inactivate microorganisms without heat [2-5]. This method is regarded as a "clean" technology that does not change food flavor, taste, or color [6]. Microorganism eradication using PEF was previously reported in processing nectar [7], milk [8], liquid 
eggs [9], and wine [10]. PEF technology applies high electric-field pulses of short duration, generally between 1-100 $\mu \mathrm{s}[11,12]$. The range of electric field is from 1 to $100 \mathrm{kV} \mathrm{cm}^{-1}$ [11-15]. The pulse shape can be a square or exponential pattern $[7,16]$, and the number of pulses can range from one to tens of thousands $[12,17,18]$. The extent of microorganism eradication depends on the applied electric parameters, the treatment chamber materials and configuration, the cell size and type, the medium osmolarity, $\mathrm{pH}$, and electrical conductivity [19-23].

It has been shown that electroporation causes pore formation and rapid breakdown of cell membrane, leading to membrane permeability [12,19]. Based on theoretical and experimental studies, this phenomenon occurs when the electric field exceeds the natural cell membrane potential. In relation to the treatment parameters mentioned above, electroporation can be divided into four ranges by its properties: irreversible with thermal damage, nonthermal irreversible, reversible, and no detectable electroporation. (1) Irreversible electroporation that is accompanied by thermal injury is characterized by protein denaturation and an imbalance of molecules released [24]. (2) Nonthermal irreversible electroporation is characterized by pore formation and slow cell resealing; or not resealing at all, leading to a release of cell contents [25]. (3) Reversible electroporation is characterized by pore and molecule movements in and out of the cell. However, a pore resealing can occur under appropriate environmental conditions, where the majority of the electroporated cells retain their viability. Pore formation may occur in less than a second, while resealing takes place in a range of minutes [26-28]. (4) Below a certain PEF strength, there is no detectable electroporation, regardless of the applied electric field and its duration $[29,30]$.

PEF-treated microorganism viability is generally estimated based on the ability to multiply. The absence of multiplication is regarded as nonexistence of microbial life [31]. However, multiplication depends on various stress and environmental conditions [32]. Live or dead microorganism designation is not clear, since the process from cell life to death, and the reverse route of recovery, are not fully understood [1,33]. Sublethally injured microorganisms, as well as viable but nonculturable (VBNC) cells, are important forms of life that may be induced by environmental and stress conditions such as hydrostatic pressure, heat treatment, pulsed light, cold plasma, ultraviolet radiation, and PEF treatment [1]. The recovery of sublethally injured yeast and VBNC cells may take place under suitable conditions [34].

In applications of microbiological stability, the addition of preservatives is an essential step following the disinfection treatments. Preservatives can prevent the recovery of the sublethally injured cells and the proliferation of VBNC microorganisms.

In food industries, sulfur dioxide $\left(\mathrm{SO}_{2}\right)$ is a common preservative and is used in particular for winemaking $[4,35]$. The advantages of $\mathrm{SO}_{2}$ as a preservative include its ability to serve as an active antioxidant that inactivates certain microorganisms. In addition, it has a positive effect on some organoleptic characteristics such as aroma complexity and color stability [35]. The disadvantages of $\mathrm{SO}_{2}$ are that it may neutralize aromatic compounds [36] and affect human health by causing allergic reactions or sensitivity [37]. Thus, many efforts are being made to find alternatives in order to minimize the use of $\mathrm{SO}_{2}$. Another common preservative is sorbic acid, and some of its salts (in particular potassium sorbate) are already widespread in food processing and pharmaceuticals. In general, sorbates have been widely accepted as effective yeast and mold inhibitors. In contrast to $\mathrm{SO}_{2}$, sorbic acid is known as a preservative with a good biocompatibility and safety profile. Varied products in the pharmaceutical and food industries with a high percentage of water, such as suspensions, emulsions, aqueous solutions, or gels, can be preserved by means of the physical or chemical interactions of sorbic acid and its salts [38,39].

In the liquid food industry, control of yeast spoilage is necessary [40]. Saccharomyces cerevisiae is known as an important microorganism for beverage production [41,42]. Compared to other microorganisms, S. cerevisiae proliferate at low $\mathrm{pH}$ levels and high alcohol concentrations. However, at the end of a beverage production process such as wine, thermal treatment is applied to avoid yeast multiplication [43]. 
In addition, there are wines, for example, classic sparkling-wine, for which, in the final production step, the yeast biomass has to be removed. Separation is mostly based on rotating and inclining the bottle until all the yeast cells settle into the bottle's neck. This method takes about 60 days [36,44]. Pretorius, 2000, described immobilization of the yeast $\left(10^{9}\right.$ cells $\left.^{-1}\right)$ in beads composed of $2 \%$ calcium alginate. This method shortened the time of yeast separation and reduced energy consumption [45]. Berovic et al. (2014) developed a rapid magnetic yeast separation in sparkling wine. The cells were absorbed to magnetized nanoparticles of iron oxide maghemite, including amino groups with a positive charge that promote electrostatic absorption of the yeast cells' negatively charged surfaces. This method led to complete yeast separation within $15 \mathrm{~min}$ [44]. PEF can serve as an alternate technology that avoids the negative effects of the heat treatment.

The aim of this work was to study the effect of electric-current density (as a consequence of the medium's conductivity) on yeast viability and membrane permeability. The recovery of the cells was examined in different media, phosphate buffered saline (PBS) or rich yeast malt broth (YMB). In addition, the viability of the yeast was examined after applying a combination of PEF technology and the addition of preservatives. This investigation was conducted on media that mimics wine characteristics, with different preservative concentrations. Our study shows the important and necessary knowledge about the yeast membrane recovery process after PEF treatment, in particular for application in the liquid food industry.

\section{Materials and Methods}

\subsection{Growth Conditions}

S. cerevisiae var. bayanus (S. cerevisiae) yeast (Lallemand Inc., Montréal, QC, Canada) was suspended in water, spread on a yeast malt (YM) (Becton Diskinson, Franklin Lakes, NJ, USA) agar plate, and incubated for $24 \mathrm{~h}$ at $37^{\circ} \mathrm{C}$. An isolated colony was taken and suspended in $12.5 \mathrm{~mL}$ yeast malt broth (YMB) with agitation at $150 \mathrm{rpm}$ at $37^{\circ} \mathrm{C}$, until it reached the mid-log phase. The culture was then centrifuged at $4000 \mathrm{~g}$ for $10 \mathrm{~min}$ at $4{ }^{\circ} \mathrm{C}$ (Avanti J-E centrifuge, Beckman Coulter, Carlsbad, CA, USA), and the sediment was washed with ultrapure (UP) water having a resistance of $18.4 \mathrm{M} \Omega-\mathrm{cm}$ at $25{ }^{\circ} \mathrm{C}$ (Synergy UV water purification system, Merck, Darmstadt, Germany). The yeast sediment was suspended in UP water and in different concentrations of PBS to a final optical density of 0.01 at $600 \mathrm{~nm}$, determined by spectrophotometer (Genesys 10S UV-VIS, Thermo Scientific, Waltham, MA, USA).

For the second part of this research, the $S$. cerevisiae yeast was grown in YMB with tartaric acid ( $\mathrm{pH}$ 3.4) until it reached the mid-log phase. Increasing ethanol concentrations were then added to the culture over a period of $5 \mathrm{~h}$ to achieve a final concentration of $10 \%$ ethanol $(v / v)$. After $2 \mathrm{~h}$, the multiplication of $S$. cerevisiae yeast was examined by spectrophotometer.

The YMB medium with the tartaric acid and the ethanol (10\%) at $\mathrm{pH} 3.5$ was used to mimic wine; it was therefore designated as YMBW (yeast malt broth wine). The $S$. cerevisiae were diluted in the YMBW medium to a final concentration of $0.02 \mathrm{OD}$ at $660 \mathrm{~nm}$.

\subsubsection{PBS Solution}

10 mM PBS (REF: 02-023-1A) was purchased from Biological Industries, Kibbutz Beit-Haemek, Israel. The PBS components were: $1.47 \mathrm{mM} \mathrm{KH}_{2} \mathrm{PO}_{4}, 8.1 \mathrm{mM} \mathrm{Na}_{2} \mathrm{HPO}_{4}, 2.67 \mathrm{mM} \mathrm{KCl}$, and $136.9 \mathrm{mM}$ $\mathrm{NaCl}$. Different PBS concentrations (0.089-0.54 mM) were obtained by dilution with UP water.

\subsubsection{Preservative Solutions}

Sorbic acid and free $\mathrm{SO}_{2}$ were prepared by dissolving potassium sorbet and potassium metabisulfite, respectively. The solubility of these materials depends on the medium properties: $\mathrm{pH}$, temperature, ethanol, and sucrose concentration. Hence, the required mass of sorbic acid was multiplied by a factor of 1.35, and the required mass of free $\mathrm{SO}_{2}$ was multiplied by a factor of 1.72 . For preparing 
high-concentration solutions, $118 \mathrm{~g}$ of potassium sorbet, $163 \mathrm{~g}$ of potassium metabisulfite, and $0.3 \mathrm{~g}$ of tartaric acid were dissolved in $\mathrm{UP} \mathrm{H}_{2} \mathrm{O}$ (100 mL final volume); the final concentrations of free $\mathrm{SO}_{2}$ and sorbic acid were $875 \mathrm{ppm}$ each, with a $\mathrm{pH}$ of 3.4. The same procedure was followed to achieve a final concentration of $1750 \mathrm{ppm}$ free $\mathrm{SO}_{2}$ and $4381 \mathrm{ppm}$ sorbic acid. Only $5 \mu \mathrm{L}$ of these solutions were inserted into $170 \mu \mathrm{L}$ treated culture. Thus, the final concentrations during the experiments were 25 ppm free $\mathrm{SO}_{2}$ and 25 ppm sorbic acid, or 50 ppm free $\mathrm{SO}_{2}$ and 125 ppm sorbic acid.

\subsubsection{The Solutions' Conductivity and $\mathrm{pH}$}

The conductivity of PBS $\left(155-1050 \mu \mathrm{cm}^{-1}\right)$, UP water $\left(1 \mu \mathrm{S} \mathrm{cm}{ }^{-1}\right)$, and YMBW, and $(1200 \mu \mathrm{S}$ $\left.\mathrm{cm}^{-1}\right)$. Conductivity was measured before the yeast inoculation, using a conductivity meter (4168, Traceable ${ }^{\circledR}$ Products, Webster, TX, USA). The pH of the PBS (4.5-5.2 \pm 0.2$)$, UP water $(4.8 \pm 0.2)$, and YMBW $(3.4 \pm 0.2)$.

\subsection{Design and Construction of the Electroporator}

2.2.1. A High-Voltage Generator Was Used for Applying an Electric Field to the S. cerevisiae Suspension

The generated voltage was adjusted to $900 \mathrm{~V}(\mathrm{U})$. The voltage pulses were controlled by a signal generator (Stanford Research System DS45, $30 \mathrm{MHz}$ (Sunnyvale, CA, USA). The voltage between the electrodes of the chamber and the current was measured using an oscilloscope (Tektronix, TDS 380, $400 \mathrm{MHz}, 2 \mathrm{GS} / \mathrm{s})$. A voltage probe that decreased the voltage $U$ by a factor of 1000 was used for measuring the chamber voltage $\mathrm{U}_{\mathrm{CH}}$, while the current $\mathrm{I}_{\mathrm{CH}}$ was measured using a Rogowski coil (an electrical device for measuring current). The current density was calculated in accordance with cross-section $\mathrm{S}\left(\mathrm{J}_{\mathrm{CH}}=\mathrm{I}_{\mathrm{CH}} / \mathrm{S}\right)$. The schematic electronic circuit is presented in Figure 1.

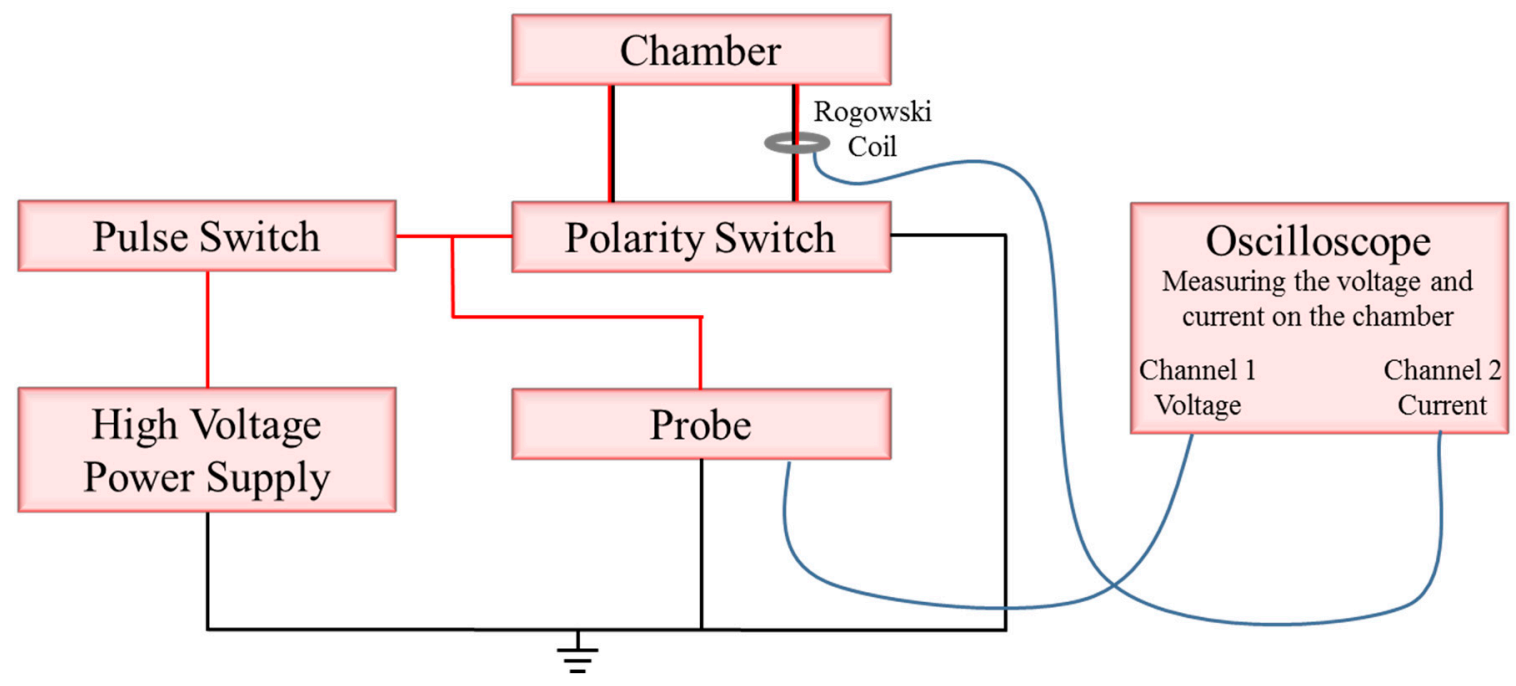

Figure 1. Schematic drawing of the high-voltage generator and the electronic circuit.

\subsubsection{Construction of the Electroporator Chamber}

The electroporate chamber was made from two stainless-steel plates, each with a thickness of $1.5 \mathrm{~mm}$ (width $32.7 \mathrm{~mm} \times$ height $33.94 \mathrm{~mm}$ ). The lower part of each electrode included a space for attaching a crocodile hook (width $47.34 \mathrm{~mm} \times$ height $11.6 \mathrm{~mm}$ ). Behind the electrodes were located two copper plates, each with a thickness of $5 \mathrm{~mm}$ and area of $1614 \mathrm{~mm}^{2}$ (width $40.1 \mathrm{~mm} \times$ height $40.26 \mathrm{~mm}$ ). The chamber size was $13.1 \mathrm{~mm}$ wide and $24.26 \mathrm{~mm}$ high. The electrodes were tightly pressed to a Teflon frame using special clamps. The chamber gap $(3.1 \mathrm{~mm})$ could be filled with $350 \mu \mathrm{L}$ up to a height of $8.7 \mathrm{~mm}$ (current cross-section $S=1.13 \mathrm{~cm}^{2}$ ). See Figure 2 and Supplementary Figure S1. 


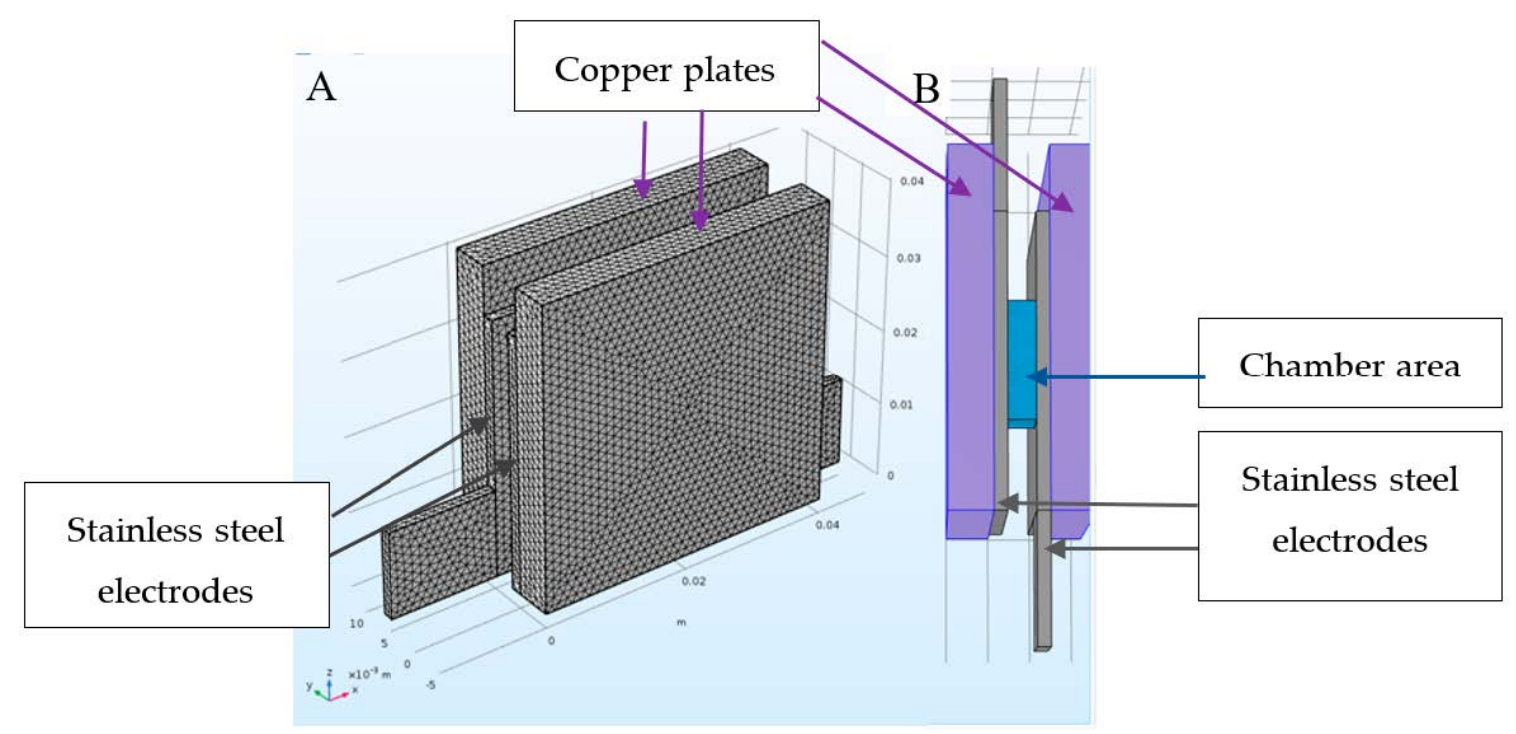

Figure 2. Schematic drawing of the electroporator chamber: A: side view, B: bottom view.

\subsection{Characterization of One Cycle of PEF Treatment}

The electric field was applied according to a previous protocol by Emanuel et al. (2019) [15], with some changes. The yeast suspensions were exposed to an electric field of $2.9 \mathrm{kV} \mathrm{cm}^{-1}$ with a frequency of $100 \mathrm{~Hz}(\mathrm{f})$ and a rectangular pulse shape, for a duration of $10 \mu \mathrm{s}(\tau)$. The number of pulses was 5000 $(\mathrm{n})$, delivered in a continuous series of 10 trains of 500 pulses each. The duration of each train was $5 \mathrm{~s}$ with a $2 \mathrm{~s}$ interval between the trains. The chamber voltage $\mathrm{U}_{\mathrm{CH}}$ polarity was switched for each train, so that the next train had the opposite polarity [15]. It is important to note that the $\mathrm{pH}$ of the solutions was examined before and after PEF treatment, and it was found that the $\mathrm{pHs}$ were not chanced. Thus, electrolysis did not take place in our experiments.

\subsection{Electro-Pulsation Procedure for Determining the Conditions of Yeast Eradication}

The yeasts were suspended in $0-0.54 \mathrm{mM}$ PBS concentrations, leading to a current of $0.03 \pm 0.01$ $-3.7 \pm 0.2 \mathrm{~A}$. The current densities were $0.02 \pm 0.01-3.3 \pm 0.1 \mathrm{~A} \mathrm{~cm}^{-2}$, with specific densities indicated for each experiment. The yeast suspension was exposed to PEF treatment as described in paragraph 2.3. The temperature was measured with a multimeter (VICHY, VC99) equipped with a k-type chromel-alumel thermocouple. The initial yeast suspension temperature was $22{ }^{\circ} \mathrm{C}$, and it did not exceed $35{ }^{\circ} \mathrm{C}$ by the end of the PEF treatment. After exposure to PEF treatment, the yeast suspensions were transferred to Eppendorf tubes and incubated at $37^{\circ} \mathrm{C}$ for $2 \mathrm{~h}$, followed by colony-forming units (CFU) analysis. When the $S$. cerevisiae in the YMBW were exposed to PEF treatment with a regime of different cycles (1-4 cycles, each as described in paragraph 2.3), the treated culture was transferred to an Eppendorf tube for a rest of $20 \pm 3 \mathrm{~min}$. This procedure was repeated as described for each experiment. The current measured on the chamber was $4 \pm 0.2 \mathrm{~A}\left(\mathrm{I}_{\mathrm{CH}}\right)$. After the last cycle, preservatives were added to the culture, followed by incubation for $24 \mathrm{~h}$ at $25^{\circ} \mathrm{C}$.

\subsection{Total Specific Energy}

The total specific energy $\left(W_{T}\right)$ was calculated as described in the work of Raso et al. (2016) [46]. Briefly, the first stage was to calculate the specific energy input per pulse $(W)$. The $W$ is the integral over time of the recorded pulse shape of voltage and current that was measured on the treatment chamber during the pulse $(\tau)$.

Equation (1):

$$
W=\frac{1}{m} \int_{0}^{\infty} U(t) \cdot I(t) d t
$$


where $m$ is the sample mass, $U(t)$ is the voltage, and $I(t)$ is the current measured on the PEF chamber during load pulse $(\tau)$. The total specific energy $\left(W_{T}\right)$ for each treatment was determined by multiplying the pulses number $(n)$ with specific energy per pulse $(W)$.

Equation (2):

$$
W_{T}=W \cdot n
$$

In this research, the number of pulses was 5000, but the energy per pulse changes in correlation to the current that was generated in line with the culture's conductivity.

\subsection{Electro-Pulsation Procedure for Determination of Membrane Permeability and Viability as a Function of Dilution in PBS and YMB Media}

The yeast suspensions $(700 \mu \mathrm{L})$ in $0.54 \mathrm{mM}$ PBS were exposed to PEF, as described in Section 2.3. The yeast suspension was then divided into three parts. One portion was examined immediately after the PEF treatment by flow cytometry (FCM) analysis and viable count assay. The second and the third portions were diluted (1:10) in $0.54 \mathrm{mM}$ PBS or YMB medium and incubated for $24 \mathrm{~h}$ at $37^{\circ} \mathrm{C}$. These yeast suspensions were sampled for FCM and CFU mL ${ }^{-1}$ analyses as described by Emanuel et al. (2019) [15]. The same procedure was conducted for the control samples, but without exposing the yeast suspension to PEF treatment.

\subsection{Examination of Yeast Membrane Permeability Using FCM Analysis}

An electro-treated yeast suspension and the nontreated control were diluted 10-fold in $0.54 \mathrm{mM}$ PBS and YMB, followed by staining with fluorescent propidium iodide (PI), as described by Emanuel et al. (2019) [15].

\subsection{Statistics}

Data are expressed as means \pm SE (standard error) of between three and five replications. The paired $t$ test was used for estimation of statistical significance. The results were considered statistically significant at $p<0.05$.

\section{Results and Discussion}

\subsection{The Effect of the Current Density on S. cerevisiae Eradication}

The S. cerevisiae (0.01 OD $600 \mathrm{~nm}$ ) in 0-0.54 mM PBS with a conductivity range of 1-1050 $\mu \mathrm{S}$ were examined in an electric field of $2.9 \mathrm{kV} \mathrm{cm}^{-1}$. The yeast suspension conductivity influenced the generated current density, which was between $0.02 \pm 0.01$ and $3.3 \pm 0.1 \mathrm{~A} \mathrm{~cm}^{-2}$. The electro-treated yeast suspensions were incubated for $2 \mathrm{~h}$ at $37^{\circ} \mathrm{C}$, and the yeast viability was examined by a viable count assay (Figure 3).

Table 1. Measured and calculated values as a function of PEF treatment in different media with $S$. cerevisiae.

\begin{tabular}{cccc}
\hline$j\left(\mathrm{~A} \mathrm{~cm}^{-\mathbf{2}}\right)$ & $\lambda_{\mathbf{0}}\left(\boldsymbol{\mu S} \mathbf{~ c m}^{-\mathbf{1}}\right)$ & $\left.\boldsymbol{W}_{\boldsymbol{T}} \mathbf{( \mathbf { k J ~ k g }}{ }^{-\mathbf{1}}\right)$ & $\Delta \mathrm{T}_{\mathbf{a v}}\left({ }^{\circ} \mathrm{C}\right)$ \\
\hline control & 1 & - & - \\
\hline 0.02 & 1 & 22.04 & $0 \pm 0.1$ \\
\hline 0.6 & 155 & 135.06 & $\mathrm{ND}$ \\
\hline 0.88 & 330 & 136.38 & $\mathrm{ND}$ \\
\hline 1.6 & 540 & 275.74 & $6 \pm 0.1$ \\
\hline 3.3 & 1030 & 614.59 & $9 \pm 0.1$
\end{tabular}

$\lambda_{0}$-medium conductivity, $j$-current density, $W_{T}$-total specific energy, $\Delta T_{a v}$-average temperature rise. ND—no data. 


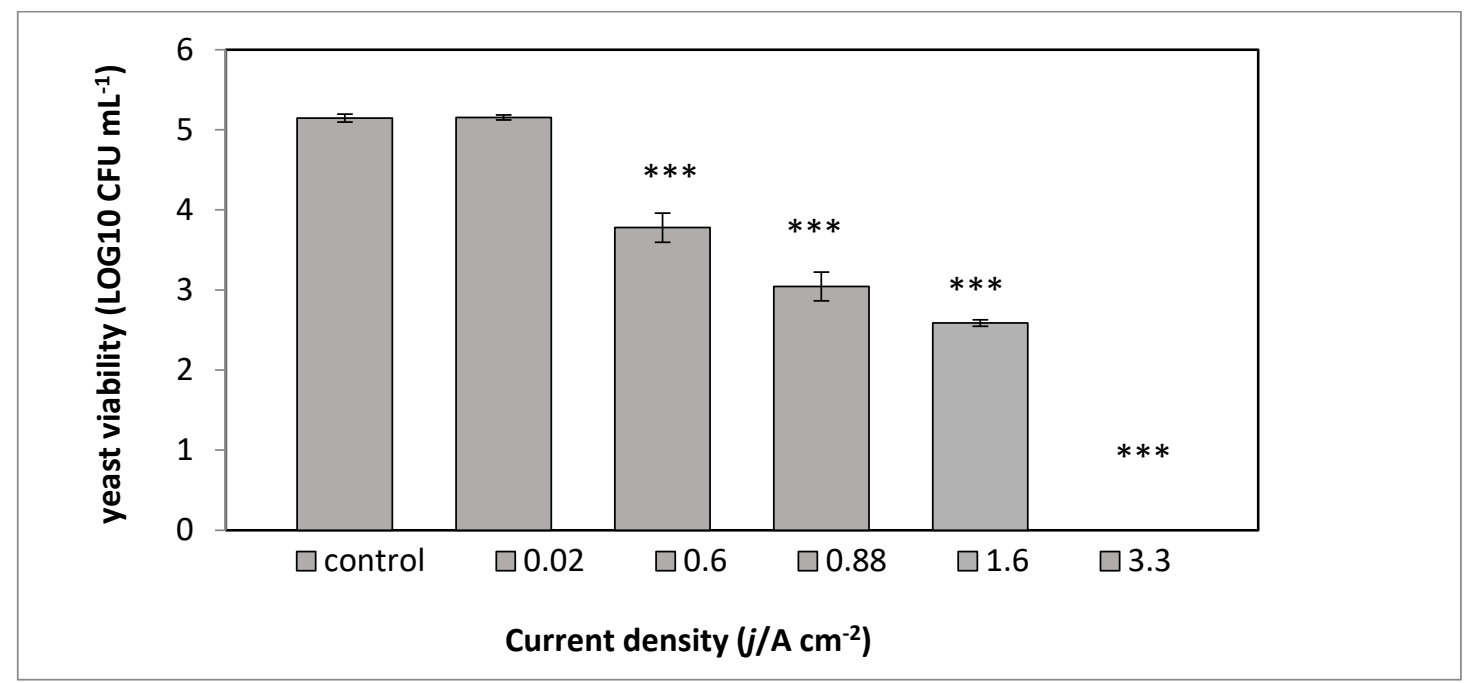

Figure 3. The effect of the current density on S. cerevisiae viability. The control consisted of yeast suspension in UP water without PEF treatment; the second column $\left(0.02 \mathrm{~A} \mathrm{~cm}^{-2}\right)$ was a yeast suspension in UP water with exposure to PEF treatment; the remaining columns $\left(0.6-3.3 \mathrm{~A} \mathrm{~cm}^{-2}\right)$ were yeast suspensions in PBS solutions with different conductivities, described in Table 1. PEF conditions: electric field intensity $2.9 \mathrm{kV} \mathrm{cm}^{-1}$, frequency $100 \mathrm{~Hz}, 5000$ pulses in trains mode of 500 each, pulse duration $10 \mu$ s. $p$ values $\left(t\right.$ test): ${ }^{* * *} p<0.001$.

S. cerevisiae (0.01 OD) suspensions in 0-0.54 mM PBS were exposed to an electric field of $2.9 \mathrm{kV}$ $\mathrm{cm}^{-1}$ with different current densities (0.02-3.3), as shown in Figure 3. PEF treatment $\left(2.9 \mathrm{kV} \mathrm{cm}^{-1}\right)$ of S. cerevisiae suspended in UP water did not influence the yeast concentration. However, when the yeasts were suspended in increasing PBS concentrations (linearly corresponding to higher medium conductivity, current density, and total specific energy), a decrease in the yeast $\mathrm{CFU} \mathrm{m}{ }^{-1}$ was observed. Total yeast death (5.15 $\log 10$ reduction) was observed at a current density of $3.3 \pm 0.1 \mathrm{~A} \mathrm{~cm}^{-2}$ and total specific energy of $614.59 \mathrm{kj} \mathrm{kg}^{-1}$.

The electroporation process is explained by an electromechanical model, where the membrane is considered an elastic dielectric capacitor. When external electric field pulses are delivered, the transmembrane potential rises, and the mechanical compression forces are increased [47]. The effect of medium conductivity is an important factor in this model. Pucihar et al. (2001) examined PEF treatments on cells with different medium conductivities of $0.001-1.6 \mathrm{~S} \mathrm{~m}^{-1}$ and found that the percentage of cell death increased with the rise in medium conductivity [22].

A study by Ou et al. (2016) [48] examined the effect of different parameters, such as electric-field strength, pulse width, and specific energy input, on membrane permeabilization and inactivation efficiency when using PEF on S. cerevisiae yeast. Their results showed that the specific energy input was the major parameter influencing cell survival [48]. Timmermans et al. (2019) studied the effect of electric-field strength $(E)$ and pulse width $(\tau)$ on various microorganisms, including $S$. cerevisiae. They found that PEF treatment at $\mathrm{E}=2.7 \mathrm{kV} \mathrm{cm}^{-1}$ and $\tau=1000 \mu \mathrm{s}$ led to a reduction of $S$. cerevisiae by 5 $\log 10$. This eradication occurred at lower temperatures, compared to equivalent thermal processes common in the food industry. The same effect was observed when the PEF conditions were $\mathrm{E}=2.7 \mathrm{kV}$ $\mathrm{cm}^{-1}$ and $\tau=100$ and $15 \mu$ s [49].

The above-mentioned studies are compatible with our results that demonstrated a decrease of cell concentration correlated to increased medium conductivity. Notably, the PEF conditions were not accompanied by high temperature, which may by itself lead to yeast death.

Many studies have shown the influence of PEF parameters on cell survival, such as conductivity, temperature rise, and total specific energy. However, relatively few studies have shown the influence of the current density on cell death. We assume that current density can also damage cells by means of charged particles that move quickly and collide with cell membranes. Bockmann and Grubmuller 
(2004) reported that different types of ions have different damaging effects on the cell membrane. The distinction between divalent or monovalent cations (often anionic) can cause a different number of bonds with the phospholipid headgroups [50]. These bonds can change the moment dipole and net tilt of headgroups. Moreover, the ion's size and charge also have an important influence on the direction and magnitude of these shifts [51]. Muraji et al. studied the influence of different extracellular ions on S. cerevisiae membrane permeability. Equally conductive solutions with different ion compositions $\left(\mathrm{MgCl}_{2}, \mathrm{NaCl}, \mathrm{KCl}, \mathrm{MgSO}_{4}\right.$ or $\left.\mathrm{CaCl}_{2}\right)$ were used for suspensions of $S$. cerevisiae. It was shown that when the cells were suspended in a solution containing $\mathrm{NaCl}$, a larger permeabilization was observed in comparison to the other ions [52].

\subsection{Viability of PEF-Treated S. cerevisiae as a Function of Suspension in YMB Medium vs. PBS}

S. cerevisiae were treated by PEF $\left(2.9 \mathrm{kV} \mathrm{cm}^{-1}\right.$, current density of $3.3 \pm 0.2 \mathrm{~A} \mathrm{~cm}^{-2}, 100 \mathrm{~Hz}, 5000$ pulses of $10 \mu \mathrm{s}$ each), and their concentration was examined during a time period of $24 \mathrm{~h}$.

The PEF-treated yeast $(0.02 \mathrm{OD} 600 \mathrm{~nm})$ was divided into three parts. A suspension of $100 \mu \mathrm{L}$ was immediately examined for CFU concentration (time ' 0 '). The second suspension of $100 \mu \mathrm{L}$ was diluted in $900 \mu \mathrm{L}$ of PBS $(0.54 \mathrm{mM})$, defined as PEF-treated yeast in PBS, and the third suspension of $100 \mu \mathrm{L}$ was diluted in $900 \mu \mathrm{L}$ YMB and was defined as PEF-treated yeast in YMB. The untreated PEF yeast suspensions were treated the same way but without exposure to PEF, defined as nontreated yeast in YMB and nontreated yeast in PBS. All the samples were incubated at $37^{\circ} \mathrm{C}$ for $24 \mathrm{~h}$, and at indicated times, a viable count assay was performed (Figure 4).

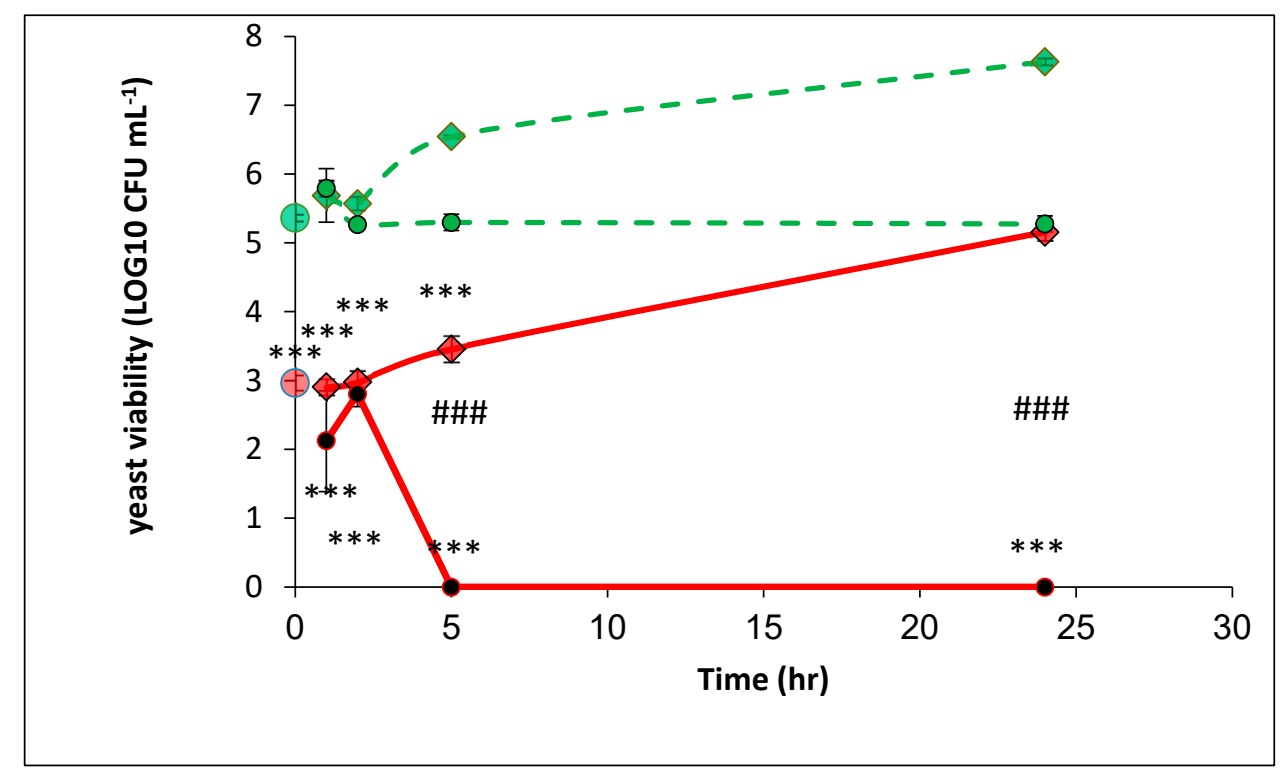

Figure 4. Yeast concentration of PEF-treated and nontreated. PEF-treated yeast in time ' 0 ' $(\bigcirc)$; nontreated yeast in time ' 0 ' $(\bullet)$; PEF-treated yeast in YMB $(1-24 \mathrm{~h})(\neg)$; PEF-treated yeast in PBS $(1-24 \mathrm{~h})(-\cdots)$; nontreated yeast in YMB $(1-24 \mathrm{~h})(-\diamond)$; nontreated yeast in PBS $(1-24 \mathrm{~h})\left(-\mathrm{O}^{-}\right) . P$ value ( $\mathrm{t}$ test): significance of the CFU count in each examined time related to its control ${ }^{* * *} p<0.001$; significance of the CFU of the treated yeast in PBS related to YMB, in each examined time \#\#\# $p<0.001$.

The PEF-treated yeast concentration at time ' 0 ' was $1.01 \cdot 10^{3}$, while the nontreated yeast sample exhibited $2.35 \times 10^{5} \mathrm{CFU} \mathrm{mL}^{-1}$ (a decrease of $2.36 \times \log 10$ ). The concentration of the nontreated yeast in PBS did not change during the entire experiment $(24 \mathrm{~h})$, and the values for CFU mL $\mathrm{m}^{-1}$ were about $2.10 \times 10^{5}$. A continued replication in the nontreated yeast in YMB was observed, and after $24 \mathrm{~h}$ it reached $4.40 \times 10^{7} \mathrm{CFU} \mathrm{mL} \mathrm{m}^{-1}$. The concentration of the PEF-treated yeast in PBS after 1 and $2 \mathrm{~h}$ were $7.5 \times 10^{2}$ and $8 \times 10^{2} \mathrm{CFU} \mathrm{mL}^{-1}$, respectively. However, no CFUs were observed $5 \mathrm{~h}$ after the PEF treatment, which held true until the end of the experiment. The PEF-treated yeasts in YMB were not 
replicated for about $2 \mathrm{~h}$, remaining at $1.16 \times 10^{3} \mathrm{CFU} \mathrm{mL} \mathrm{L}^{-1}$. However, after $2 \mathrm{~h}$ the cells continued to replicate and reached $1.66 \times 10^{5} \mathrm{CFU} \mathrm{mL}^{-1}$.

In conclusion, when the yeasts were suspended in PBS $(0.54 \mathrm{mM})$ and treated by PEF, a reduction of $2.36 \log 10$ in time ' 0 ' was observed. No CFUs were observed at 5 and $24 \mathrm{~h}$ after the PEF treatment. However, the yeast cells suspended in YMB continued to replicate, and after $24 \mathrm{~h}$ they reached $1.66 \cdot 10^{5}$ CFU mL ${ }^{-1}$.

Recent studies have shown the existence of sublethally injured S. cerevisiae after exposure to PEF treatment [53]. This phenomenon depends on the treatment conditions (medium, electric-field strength, number of pulses, pulse shape, and duration, etc.). The effect of different media on the recovery of injured S. cerevisiae cells after PEF treatment was therefore examined. After PEF treatment (50 pulses at $12.0 \mathrm{kV} \mathrm{cm}^{-1}$ at $\mathrm{pH} 4.0$ or 7.0), sublethal injury of yeast cells was detected. Use of Sabouraud dextrose broth led to maximum repair of the injured yeasts, compared to citrate-phosphate buffer (pH 7.0) or peptone water ( $\mathrm{pH}$ 4.0). In citrate-phosphate buffer, no repair was observed, while a higher extent of PEF-treated S. cerevisiae repair and survival was observed in the acid conditions [34].

The recovery of sublethally injured S. cerevisiae has also been reported when the cells were exposed to thermal or chemical stresses [54]. Zakhem et al. studied how PEF-treated S. cerevisiae are affected by moderate electric fields when $\mathrm{E}<7.5 \mathrm{kV} \mathrm{cm}^{-1}$. The observed damage in the early stages was not complete and continued to develop a long time after the PEF treatment [55]. Our results also found a developing damage that continued for several hours after the PEF treatment. When treated yeast was suspended in PBS, a decrease in the CFU ml ${ }^{-1}$ was shown. However, only after $5 \mathrm{~h}$ was total eradication observed.

\subsection{Membrane Permeability of PEF-Treated S. cerevisiae When Suspended in YMB vs. PBS}

A yeast suspension $(0.02 \mathrm{OD} 600 \mathrm{~nm})$ in $0.54 \mathrm{mM}$ PBS was divided into three parts, as described in Section 3.2. The yeast suspensions were incubated at $37^{\circ} \mathrm{C}$ for $24 \mathrm{~h}$, and at indicated times $(0,1.5$, 3, and $24 \mathrm{~h}$ ) $1.8 \mu \mathrm{L}$ of propidium iodide (PI) was added to a sample of $120 \mu \mathrm{L}$ for 5 min incubation, followed by analyzing the membrane permeability by FCM (Figure 5).

As shown in Figure 5, the percentage of the PI-positive PEF-treated yeast (suspended in PBS) at time ' 0 ' was $98 \pm 0.3 \%$. In contrast, the nontreated samples (both YMB and PBS) exhibited only a low PI-positive percentage of about $1.5 \pm 0.1 \%$, which was observed throughout the $24 \mathrm{~h}$ of the experiment.

The PI-positive percentages of PEF-treated yeast in YMB after 1.5 and $3 \mathrm{~h}$ were $97 \pm 0.4 \%$ and $94 \pm$ $0.8 \%$, respectively. Similar results were observed with PEF-treated yeast in PBS: $98 \pm 0.3 \%$ and $98 \pm$ $0.2 \%$, respectively. In contrast, after $24 \mathrm{~h}$, the PI-positive percentages of PEF-treated yeast in YMB were about $4 \pm 1 \%$, compared to $97 \pm 0.3 \%$ of PEF-treated yeast in PBS.

We assume that the low PI-positive percentages seen at time '24' (PEF-treated yeast in YMB) are a result of a membrane repair mechanism in this rich medium. The same result was observed in yeast multiplication, as shown in Figure 4. Neither yeast multiplication nor membrane recovery occurred when the cells were suspended in PBS (Figure 4), and high membrane permeability was confirmed by the data in Figure 5.

The mechanisms of prolonged membrane permeability, which continued long after pulse delivery, remain unclear. Several studies have explained the resealing process via a "molecular" mechanism such as lipid peroxidation [56,57]. In contrast, Stirke et al. (2019) studied the cell resealing process of $S$. cerevisiae yeast and suggested that the recovery process is "mechanical" in nature; it may be attributed to changes of osmotic pressure during electroporation and the processes taking place after PEF [58].

Our results showed that PEF-treated S. cerevisiae membrane permeability lasted for a few hours. This phenomenon was observed when the cells were suspended in PBS as well as in YMB. However, in the rich YMB medium membrane, recovery was observed after $24 \mathrm{~h}$. We assume that the richness of the medium enabled a recovery process unattainable for cells suspended in PBS (which includes only salts). These conclusions are important for the implementation of PEF technology in the food industry. 


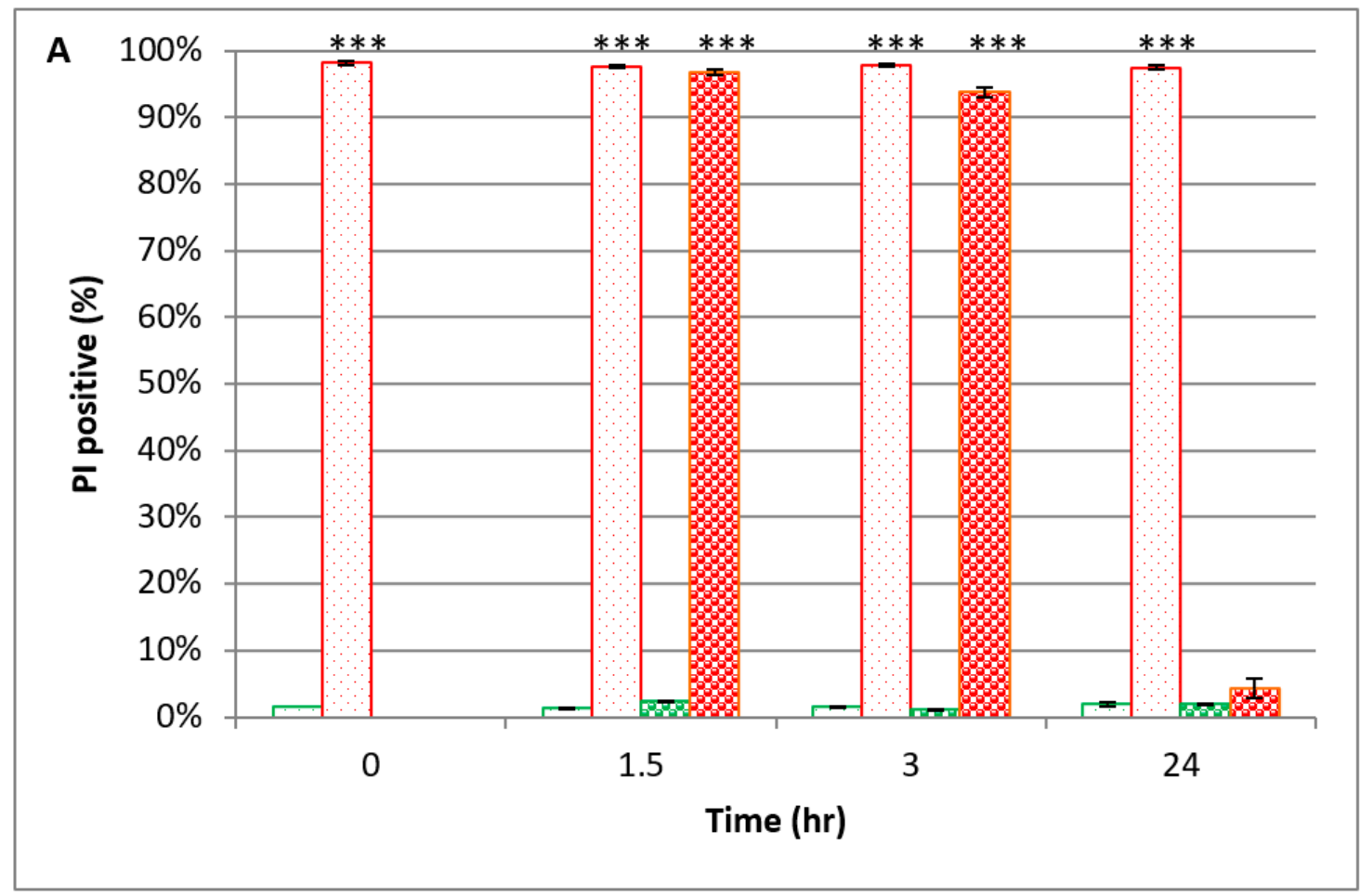

Figure 5. Examination of $S$. cerevisiae membrane permeability. PEF-treated yeasts, which were suspended in YMB (1.5-24 h) (四); PEF-treated yeasts, which were suspended in PBS (0-24 h) (D); nontreated yeasts, which were suspended in YMB (1.5-24 h) (घ); nontreated yeasts, which were suspended in PBS (0-24 h) (D). P value (t test): ${ }^{* * *} p<0.001$.

\subsection{Yeast Eradication as a Function of PEF Treatment-Cycle Mode}

As mentioned, the S. cerevisiae were grown in YMB with tartaric acid ( $\mathrm{pH}$ 3.4) to the mid-log phase. This was followed by addition of ethanol to a final concentration of $10 \%(v / v)$ and $3.4 \mathrm{pH}$ (designated as $\mathrm{YMBW}$ ). After $2 \mathrm{~h}$ of growth following the addition of ethanol, the culture was diluted to a final concentration of $0.02 \mathrm{OD}$ at $600 \mathrm{~nm}$. Then the $S$. cerevisiae was exposed to PEF treatment: $2.9 \mathrm{kV} \mathrm{cm}^{-1}$ at a current density of $4 \pm 02 \mathrm{~A} \mathrm{~cm}^{-2}$, frequency of $100 \mathrm{~Hz}$, pulse duration of $10 \mu \mathrm{s}$, with 5000 pulses (the described PEF treatment condition was designated as "cycle"). The treated culture was transferred to an Eppendorf tube for a rest of $20 \pm 3$ min before exposure to another PEF cycle. The yeast culture was treated in one to four cycles, as indicated in the experiment.

The PEF-treated S. cerevisiae culture was immediately ("0 time") after each PEF treatment examined for $\mathrm{CFU} \mathrm{mL} \mathrm{m}^{-1}$ (Figure 6).

As shown in Figure 6, one cycle of PEF treatment led to a reduction of $1.35 \log 10$ compared to the control. However, increasing PEF cycles from one to four increased the yeast mortality by only a 0.89 $\log 10$ reduction. In other words, addition of PEF treatment cycles enhanced the yeast eradication, but the influence of the first PEF treatment cycle on S. cerevisiae eradication was more significant compared to the subsequent cycles. 


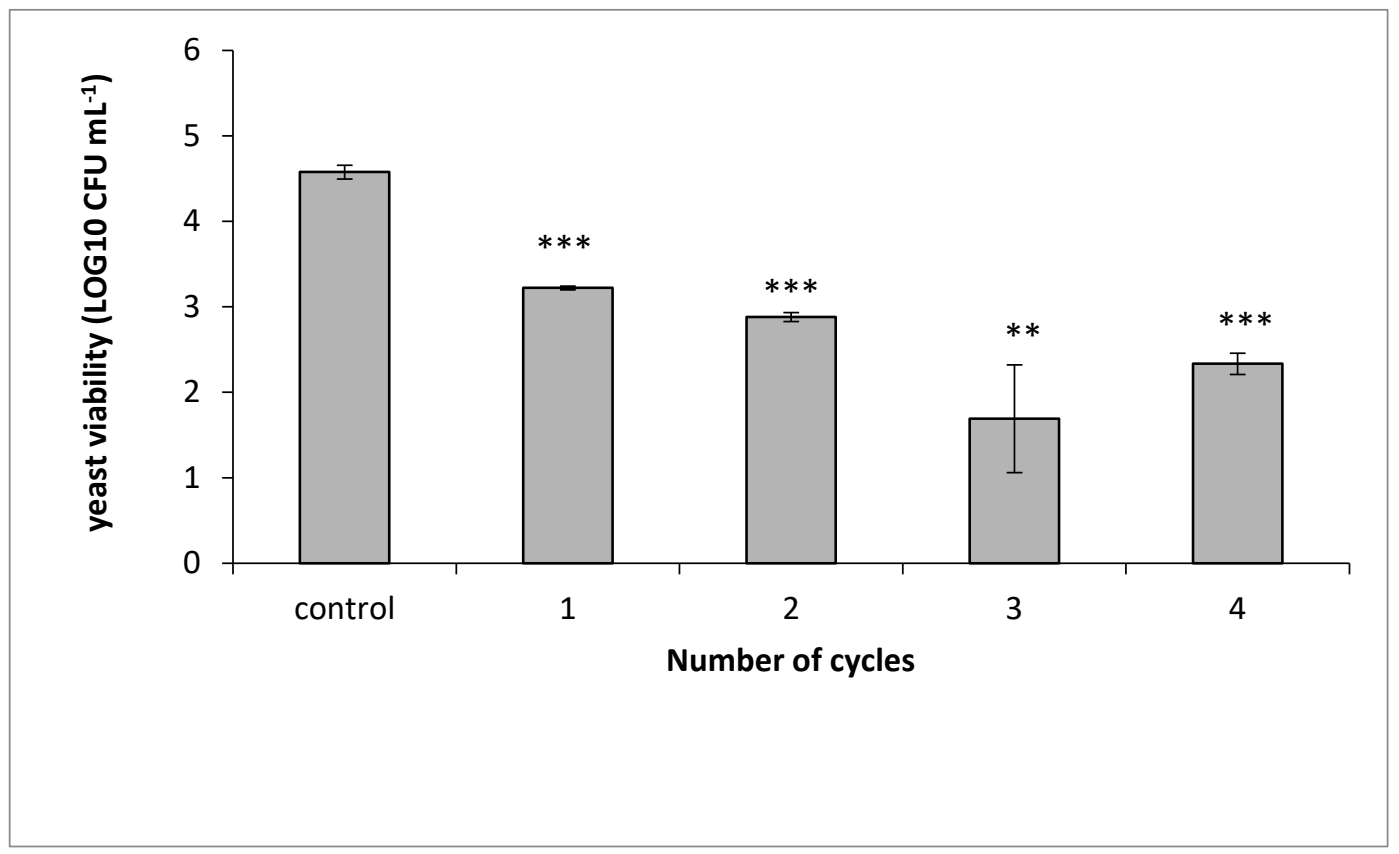

Figure 6. Viability of S. cerevisiae in YMBW as a function of PEF treatment cycles. The control column represents the CFU mL $\mathrm{m}^{-1}$ of yeast cells without PEF treatment. Columns 1-4 are the number of treatment cycles applied to the yeast culture. The conditions of each PEF cycle: electric-field intensity $2.9 \mathrm{kV} \mathrm{cm}^{-1}$, frequency $100 \mathrm{~Hz}$, pulse duration $10 \mu \mathrm{s}$, conductivity $1200 \mu \mathrm{S}$. $p$ value ( $t$ test): ${ }^{* *} p<0.01$; *** $p<0.001$.

\subsection{S. cerevisiae Eradication as a Function of Combined PEF Treatment and Preservative}

The $S$. cerevisiae at their $\log$ phase in YMBW $(0.02 \mathrm{OD}$ at $600 \mathrm{~nm})$ were exposed to different numbers of PEF treatment cycles (each cycle: $2.9 \mathrm{kV} \mathrm{cm}^{-1}$ at current density of $4 \pm 0.2 \mathrm{~A} \mathrm{~cm}^{-2}$, frequency of $100 \mathrm{~Hz}$, pulse duration of $10 \mu \mathrm{s}$ with 5000 pulses, $20 \pm 3 \mathrm{~min}$ break between each cycle; more details in Section 2.4). At the end of the PEF-treatment cycles, a solution of free $\mathrm{SO}_{2}$ and sorbic acid was added to achieve a final concentration of $25 \mathrm{ppm}$ free $\mathrm{SO}_{2}$ and $25 \mathrm{ppm}$ sorbic acid. The PEF-treated and non-treated S. cerevisiae with and without the preservatives incubated for $24 \mathrm{~h}$ at $25^{\circ} \mathrm{C}$. A viable count assay was performed at the end of incubation.

A similar procedure was conducted for two additional sets, except for varying the added concentrations of free $\mathrm{SO}_{2}$ and sorbic acid. For one set, the final concentration of the treated cultures was $50 \mathrm{ppm}$ free $\mathrm{SO}_{2}$ and $125 \mathrm{ppm}$ sorbic acid. In the other set, no preservatives were added.

The next steps of the procedure were the same as described at the beginning of this experiment ( $24 \mathrm{~h}$ of incubation at $25^{\circ} \mathrm{C}$, followed by CFU mL ${ }^{-1}$ analysis). Results are shown in Figure 7 .

As shown in Figure 7, the control sample without the preservatives exhibited a CFU mL $\mathrm{m}^{-1}$ that was two orders of magnitude higher than the control samples with either high or low concentrations of preservatives. Regarding length of PEF treatment (1-4 cycles), the CFU mL ${ }^{-1}$ values in the cultures that were only PEF-treated (where no preservatives were added) were about the same compared to the samples of yeast culture with preservative and that were exposed to PEF.

The eradication increased along with the increase in the number of PEF treatment cycles. The addition of the preservatives did not lead to higher reduction in the yeast concentration compared to the sample that was exposed to PEF without the preservatives. 


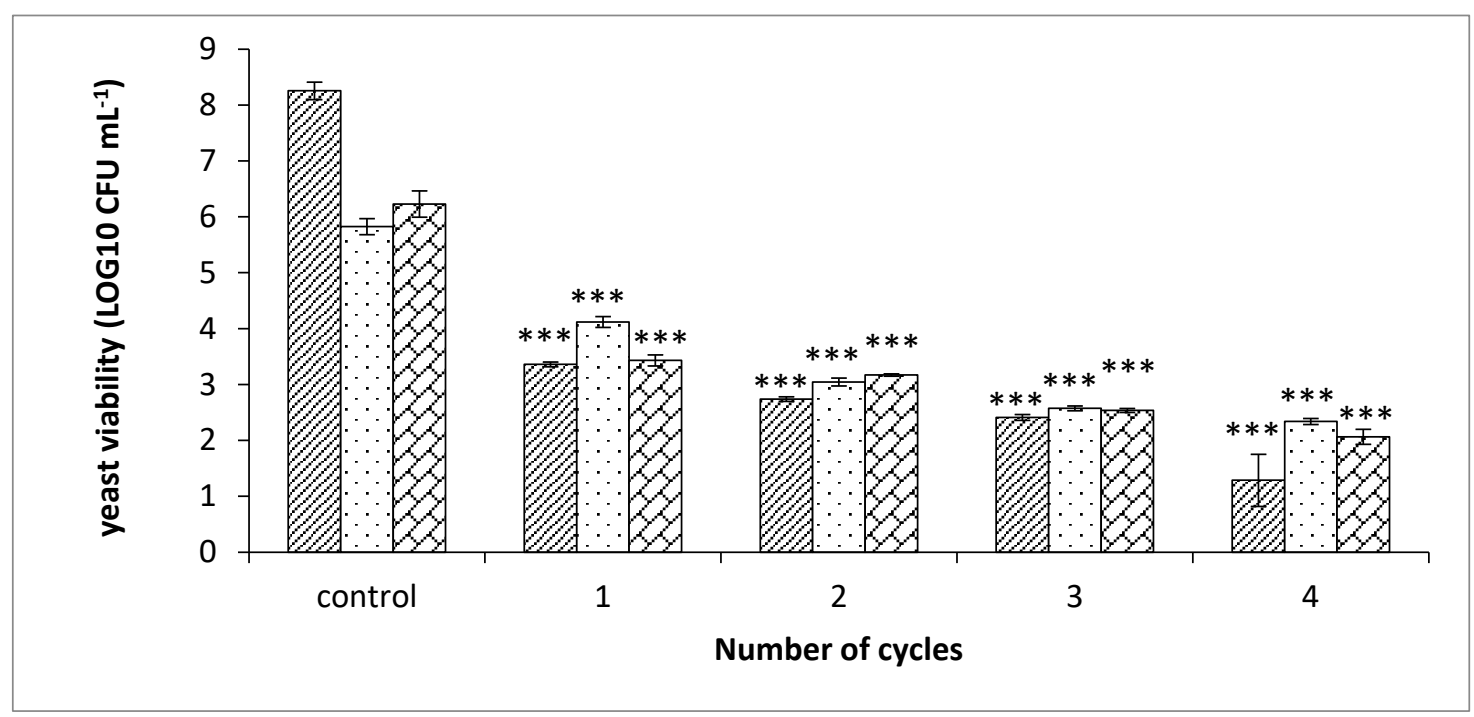

Figure 7. Viability of $S$. cerevisiae in YMBW after $24 \mathrm{~h}$ of incubation at $25^{\circ} \mathrm{C}$, as a function of PEF treatment cycle numbers and added preservatives. The control columns represent the CFU mL ${ }^{-1}$ of yeast without PEF treatment. Column groups 1-4 represent the number of cycles that were applied to the yeast culture. No added preservatives (四); added 25 ppm free $\mathrm{SO}_{2}$ and 25 ppm sorbic acid (G); added 50 ppm free $\mathrm{SO}_{2}$ and 125 ppm sorbic acid $(\varangle)$. The conditions of each PEF cycle: electric field intensity $2.9 \mathrm{kV} \mathrm{cm}^{-1}$, frequency $100 \mathrm{~Hz}$, pulse duration $10 \mu \mathrm{s}$, conductivity $1200 \mu \mathrm{S} \mathrm{cm}^{-1}$. $p$ value $(t$ test): ${ }^{* * *} p<0.001$.

In conclusion, the added PEF treatment cycles improved the eradication of S. cerevisiae, while a synergic effect was not observed when free $\mathrm{SO}_{2}$ and sorbic acid were added.

Due to the necessity of finding different techniques for inactivating microorganisms in the food industry as alternatives to heat treatments [40,50], Montanari et al. studied the combined effect of PEF and citral preservative on S. cerevisiae inactivation. Following citral insertion, the log reduction increased approximately by 1.5 fold, compared to PEF treatments without citral. Although synergism was not always observed, Somolinos et al. (2007) reported that membrane permeabilization induced by PEF can improve the penetration of preservatives. However, PEF treatment along with the addition of sorbic acid did not enhance the inactivation of $S$. cerevisiae in this manner when the concentration was less than 200 ppm [59].

\section{Conclusions}

When PEF treatment $\left(2.9 \mathrm{kV} \mathrm{cm}^{-1}\right)$ was used on $S$. cerevisiae suspended in increasing PBS concentrations (linearly corresponding to higher medium conductivity, current density, and total specific energy), a decrease in yeast concentration was observed. The type of medium (rich or PBS) was critical for the success of injured yeast recovery, or alternately for continued damage development until total eradication. Additional PEF treatment cycles improved the eradication of S. cerevisiae. However, a synergic effect was not observed when free $\mathrm{SO}_{2}$ and sorbic acid were added. This study shows the important and necessary knowledge about yeast viability and membrane recovery after PEF treatment, in particular for applicability in the liquid food industry.

Supplementary Materials: The following are available online at http://www.mdpi.com/2076-2607/8/11/1684/s1. Figure S1. Photos of electroporator chamber and the instrument.

Author Contributions: Conceptualization and methodology: R.C., R.P., and E.E.; contributions to the experiment: E.E., R.P., I.D., and E.H.; experimental data analysis: E.E. and G.A.P.; investigation: E.E.; research administration and supervision: R.C. and R.P.; writing, original draft preparation: R.C. and E.E.; writing-review and editing, R.C., G.A.P., and E.E. All authors have read and agreed to the published version of the manuscript. 
Funding: We would like to thank the Israel Ministry of Science, Technology, and Space for providing funding (grant number: 3-13695) to Ms. Efrat Emanuel under the fellowship category of Outstanding PhD Researchers.

Conflicts of Interest: No conflict of interest is disclosed for the work reported in this study.

\section{References}

1. Schottroff, F.; Fröhling, A.; Zunabovic-Pichler, M.; Krottenthaler, A.; Schlüter, O.; Jäger, H. Sublethal injury and Viable but Non-culturable (VBNC) state in microorganisms during preservation of food and biological materials by non-thermal processes. Front. Microbiol. 2018, 9, 1-19. [CrossRef] [PubMed]

2. Barba, F.J.; Parniakov, O.; Pereira, S.A.; Wiktor, A.; Grimi, N.; Boussetta, N.; Saraiva, J.A.; Raso, J.; Martin-Belloso, O.; Witrowa-Rajchert, D.; et al. Current applications and new opportunities for the use of pulsed electric fields in food science and industry. Food Res. Int. 2015, 77, 773-798. [CrossRef]

3. Tylewicz, U.; Tappi, S.; Mannozzi, C.; Romani, S.; Dellarosa, N.; Laghi, L.; Ragni, L.; Rocculi, P.; Dalla Rosa, M. Effect of pulsed electric field (PEF) pre-treatment coupled with osmotic dehydration on physico-chemical characteristics of organic strawberries. J. Food Eng. 2017, 213, 2-9. [CrossRef]

4. González-arenzana, L.; Reinares, J.P.; López, N.; Santamaría, P.; Garde-cerdán, T.; Gutiérrez, A.R.; López-alfaro, I.; López, R. Impact of Pulsed Electric Field Treatment on Must and Wine Quality. In Handbook of Electroporation; Miklavčič, D., Ed.; Springer: Berlin, Germany, 2017; pp. 2391-2406. ISBN 9783319328867.

5. Mathys, A.; Reineke, K.; Jäger, H. Editorial: Microbial decontamination by novel technologies -mechanisms and application concepts. Front. Microbiol. 2019, 10, 1-2. [CrossRef] [PubMed]

6. Martin, O.; Qin, B.L.; Chang, F.J.; Barbosa-Canovas, G.V.; Swanson, B.G. Inactivation of Escherichia Coli in skim milk by high intensity pulsed electric fields. J. Food Process Eng. 1997, 20, 317-336. [CrossRef]

7. Evrendilek, G.A.; Altuntas, J.; Sangun, M.K.; Zhang, H.Q. Apricot nectar processing by pulsed electric fields. Int. J. Food Prop. 2013, 16, 216-227. [CrossRef]

8. Sobrino-López, A.; Martin-Belloso, O. Review: Potential of high-intensity pulsed electric field technology for milk processing. Food Eng. Rev. 2009, 2, 17-27. [CrossRef]

9. Amiali, M.; Ngadi, M.O.; Smith, J.P.; Raghavan, V.G.S. Inactivation of Escherichia coli O157:H7 and Salmonella enteritidis in liquid egg white using pulsed electric field. J. Food Sci. 2006, 71, M88-M94. [CrossRef]

10. Puertolas, E.; Lopez, N.; Condon, S.; Raso, J.; Alvarez, I. Pulsed electric fields inactivation of wine spoilage yeast and bacteria. Int. J. Food Microbiol. 2009, 130, 49-55. [CrossRef]

11. Guionet, A.; David, F.; Zaepffel, C.; Coustets, M.; Helmi, K.; Cheype, C.; Packan, D.; Garnier, J.P.; Blanckaert, V.; Teissie, J. E. coli electroeradication on a closed loop circuit by using milli-, micro- and nanosecond pulsed electric fields: Comparison between energy costs. Bioelectrochemistry 2015, 103, 65-73. [CrossRef]

12. Coustets, M.; Ganeva, V.; Galutzov, B.; Teissie, J. Millisecond duration pulses for flow-through electro-induced protein extraction from E. coli and associated eradication. Bioelectrochemistry 2015, 103, 82-91. [CrossRef] [PubMed]

13. Sale, A.J.H.; Hamilton, W.A. Effects of high electric fields on microorganisms: I. Killing of bacteria and yeasts. Biochim. Biophys. Acta Gen. Subj. 1967, 148, 781-788. [CrossRef]

14. Jayaram, S.; Castle, G.S.P.; Margaritis, A. The effects of high field DC pulse and liquid medium conductivity on survivability of Lactobacillus brevis. Appl. Microbiol. Biotechnol. 1993, 40, 117-122. [CrossRef]

15. Emanuel, E.; Roman, P.; Cahan, R. Influence of the current density in moderate pulsed electric fields on $P$. putida F1 eradication. Bioelectrochemistry 2019, 126, 172-179. [CrossRef] [PubMed]

16. Canatella, P.J.; Karr, J.F.; Petros, J.A.; Prausnitz, M.R. Quantitative study of electroporation-mediated molecular uptake and cell viability. Biophys. J. 2001, 80, 755-764. [CrossRef]

17. French, D.M.; Uhler, M.D.; Gilgenbach, R.M.; Lau, Y.Y. Conductive versus capacitive coupling for cell electroporation with nanosecond pulses. J. Appl. Phys. 2009, 106. [CrossRef]

18. Khan, S.I.; Blumrosen, G.; Vecchio, D.; Golberg, A.; Mccormack, M.C.; Yarmush, M.L.; Hamblin, M.R.; Austen, W.G. Eradication of multidrug-resistant pseudomonas biofilm with pulsed electric fields. Biotechnol. Bioeng. 2016, 113, 643-650. [CrossRef]

19. Neumann, E.; Schaefer-Ridder, M.; Wang, Y.; Hofschneider, P.H. Gene transfer into mouse lyoma cells by electroporation in high electric fields. EMBO J. 1982, 1, 841-845. [CrossRef] 
20. Reineke, K.; Schottroff, F.; Meneses, N.; Knorr, D. Sterilization of liquid foods by pulsed electric fields-an innovative ultra-high temperature process. Front. Microbiol. 2015, 6, 400. [CrossRef]

21. Alkhafaji, S.R.; Farid, M. An investigation on pulsed electric fields technology using new treatment chamber design. Innov. Food Sci. Emerg. Technol. 2007, 8, 205-212. [CrossRef]

22. Pucihar, G.; Kotnik, T.; Kandušer, M.; Miklavčič, D. The influence of medium conductivity on electropermeabilization and survival of cells in vitro. Bioelectrochemistry 2001, 54, 107-115. [CrossRef]

23. Baldwin, W.H.; Gregory, B.W.; Osgood, C.J.; Schoenbach, K.H.; Kolb, J.F. Membrane permeability and cell survival after nanosecond pulsed-electric-field exposure-significance of exposure-media composition. IEEE Trans. Plasma Sci. 2010, 38, 2948-2953. [CrossRef]

24. Kotnik, T.; Frey, W.; Sack, M.; Haberl Meglič, S.; Peterka, M.; Miklavčič, D. Electroporation-based applications in biotechnology. Trends Biotechnol. 2015, 33, 480-488. [CrossRef] [PubMed]

25. Yarmush, M.L.; Golberg, A.; Serša, G.; Kotnik, T.; Miklavčič, D. Electroporation-based technologies for medicine: Principles, applications, and challenges. Ann. Rev. Biomed. Eng. 2014, 16, 295-320. [CrossRef] [PubMed]

26. Kinosita, K.; Tsong, T.Y. Voltage-induced pore formation and hemolysis of human erythrocytes. $B B A$ Biomembr. 1977, 471, 227-242. [CrossRef]

27. Rols, M.P.; Teissié, J. Electropermeabilization of mammalian cells. Quantitative analysis of the phenomenon. Biophys. J. 1990, 58, 1089-1098. [CrossRef]

28. Lee, R.; River, L.P.; Pan, F.-S.; Ji, L.; Wollmann, R.L. Surfactant-induced sealing of electropermeabilized skeletal muscle membranes in vivo. Proc. Natl. Acad. Sci. USA 1992, 89, 4524-4528. [CrossRef]

29. Kramar, P.; Miklavcic, D.; Lebar, A.M. Determination of the lipid bilayer breakdown voltage by means of linear rising signal. Bioelectrochemistry 2007, 70, 23-27. [CrossRef]

30. Pucihar, G.; Krmelj, J.; Reberšek, M.; Napotnik, T.B.; Miklavčič, D. Equivalent pulse parameters for electroporation. IEEE Trans. Biomed. Eng. 2011, 58, 3279-3288. [CrossRef]

31. Emerson, J.B.; Adams, R.I.; Román, C.M.B.; Brooks, B.; Coil, D.A.; Dahlhausen, K.; Ganz, H.H.; Hartmann, E.M.; Hsu, T.; Justice, N.B.; et al. Schrödinger's microbes: Tools for distinguishing the living from the dead in microbial ecosystems. Microbiome 2017, 5. [CrossRef]

32. Davis, C. Enumeration of probiotic strains: Review of culture-dependent and alternative techniques to quantify viable bacteria. J. Microbiol. Methods 2014, 103, 9-17. [CrossRef] [PubMed]

33. Davey, H.M. Life, death, and in-between: Meanings and methods in microbiology. Appl. Environ. Microbiol. 2011, 77, 5571-5576. [CrossRef] [PubMed]

34. Somolinos, M.; Mañas, P.; Condón, S.; Pagán, R.; García, D. Recovery of Saccharomyces cerevisiae sublethally injured cells after Pulsed Electric Fields. Int. J. Food Microbiol. 2008, 125, 352-356. [CrossRef] [PubMed]

35. Marchante, L.; Loarce, L.; Izquierdo-Cañas, P.M.; Alañón, M.E.; García-Romero, E.; Pérez-Coello, M.S.; Díaz-Maroto, M.C. Natural extracts from grape seed and stem by-products in combination with colloidal silver as alternative preservatives to $\mathrm{SO}_{2}$ for white wines: Effects on chemical composition and sensorial properties. Food Res. Int. 2019, 125, 108594. [CrossRef]

36. Ribéreau-Gayon, P.; Dubourdieu, D.; Donèche, B.; Lonvaud, A. Handbook of Enology, Volume 1: The Microbiology of Wine and Vinifications; John Wiley \& Sons: Hoboken, NJ, USA, 2006; Volume 1, ISBN 0470010355.

37. Santos, M.C.; Nunes, C.; Saraiva, J.A.; Coimbra, M.A. Chemical and physical methodologies for the replacement/reduction of sulfur dioxide use during winemaking: Review of their potentialities and limitations. Eur. Food Res. Technol. 2012, 234, 1-12. [CrossRef]

38. Sofos, J.N.; Pierson, M.D.; Blocher, J.C.; Busta, F.F. Mode of action of sorbic acid on bacterial cells and spores. Int. J. Food Microbiol. 1986, 3, 1-17. [CrossRef]

39. Nemes, D.; Kovács, R.; Nagy, F.; Tóth, Z.; Herczegh, P.; Borbás, A.; Kelemen, V.; Pfliegler, W.P.; Rebenku, I.; Hajdu, P.B.; et al. Comparative biocompatibility and antimicrobial studies of sorbic acid derivates. Eur. J. Pharm. Sci. 2020, 143. [CrossRef]

40. Montanari, C.; Tylewicz, U.; Tabanelli, G.; Berardinelli, A.; Rocculi, P.; Ragni, L.; Gardini, F. Heat-assisted pulsed electric field treatment for the inactivation of Saccharomyces cerevisiae: Effects of the presence of citral. Front. Microbiol. 2019, 10. [CrossRef]

41. Sperber, W.H.; Doyle, M.P. Compendium of the Microbiological Spoilage of Foods and Beverages; Springer: New York, NY, USA, 2009. 
42. da Cruz Almeida, E.T.; de Medeiros Barbosa, I.; Tavares, J.F.; Barbosa-Filho, J.M.; Magnani, M.; de Souza, E.L. Inactivation of spoilage yeasts by Mentha spicata L. and M. $\times$ villosa Huds. essential oils in cashew, guava, mango, and pineapple juices. Front. Microbiol. 2018, 9, 1111. [CrossRef]

43. Tabanelli, G.; Montanari, C.; Arioli, S.; Magnani, M.; Patrignani, F.; Lanciotti, R.; Mora, D.; Gardini, F. Physiological response of Saccharomyces cerevisiae to citral combined with thermal treatment. LWT 2019, 101, 827-834. [CrossRef]

44. Berovic, M.; Berlot, M.; Kralj, S.; Makovec, D. A new method for the rapid separation of magnetized yeast in sparkling wine. Biochem. Eng. J. 2014, 77-84. [CrossRef]

45. Pretorius, I.S. Tailoring wine yeast for the new millennium: Novel approaches to the ancient art of winemaking. Yeast 2000, 16, 675-729. [CrossRef]

46. Raso, J.; Frey, W.; Ferrari, G.; Pataro, G.; Knorr, D.; Teissie, J.; Miklavčič, D. Recommendations guidelines on the key information to be reported in studies of application of PEF technology in food and biotechnological processes. Innov. Food Sci. Emerg. Technol. 2016, 37, 312-321. [CrossRef]

47. Tylewicz, U. How does pulsed electric field work? In Pulsed Electric Fields to Obtain Healthier and Sustainable Food for Tomorrow; Academic Press: Cambridge, MA, USA, 2020; ISBN 9780128164020.

48. Ou, Q.; Nikolic-Jaric, M. Mechanisms of inactivation of Candida humilis and Saccharomyces cerevisiae by pulsed electric fields. Bioelectrochemistry 2016, 115. [CrossRef]

49. Timmermans, R.A.H.; Mastwijk, H.C.; Berendsen, L.B.J.M.; Nederhoff, A.L.; Matser, A.M.; Van Boekel, M.A.J.S.; Nierop Groot, M.N. Moderate intensity Pulsed Electric Fields (PEF) as alternative mild preservation technology for fruit juice. Int. J. Food Microbiol. 2019, 298, 63-73. [CrossRef]

50. Böckmann, R.A.; Grubmüller, H. Multistep binding of divalent cations to phospholipid bilayers: A molecular dynamics study. Angew. Chemie Int. Ed. 2004, 43, 1021-1024. [CrossRef]

51. Sachs, J.N.; Nanda, H.; Petrache, H.I.; Woolf, T.B. Changes in phosphatidylcholine headgroup tilt and water order induced by monovalent salts: Molecular dynamics simulations. Biophys. J. 2004, 86, 3772-3782. [CrossRef]

52. Muraji, M.; Tatebe, W.; Berg, H. The influence of extracellular alkali and alkaline-earth ions on electropermeation of Saccharomyces cerevisiae. Bioelectrochem. Bioenerg. 1998, 46, 293-295. [CrossRef]

53. Paniagua-Martínez, I.; Ramírez-Martínez, A.; Serment-Moreno, V.; Rodrigues, S.; Ozuna, C. Non-thermal technologies as alternative methods for Saccharomyces cerevisiae inactivation in liquid media: A Review. Food Bioprocess Technol. 2018, 11, 487-510. [CrossRef]

54. Davey, H.M.; Hexley, P. Red but not dead? Membranes of stressed Saccharomyces cerevisiae are permeable to propidium iodide. Environ. Microbiol. 2011, 13, 163-171. [CrossRef]

55. El Zakhem, H.; Lanoisellé, J.L.; Lebovka, N.I.; Nonus, M.; Vorobiev, E. The early stages of Saccharomyces cerevisiae yeast suspensions damage in moderate pulsed electric fields. Colloids Surfaces B Biointerfaces 2006, 47, 189-197. [CrossRef] [PubMed]

56. Rems, L.; Viano, M.; Kasimova, M.A.; Miklavčič, D.; Tarek, M. The contribution of lipid peroxidation to membrane permeability in electropermeabilization: A molecular dynamics study. Bioelectrochemistry 2019, 125, 46-57. [CrossRef] [PubMed]

57. Breton, M.; Mir, L.M. Investigation of the chemical mechanisms involved in the electropulsation of membranes at the molecular level. Bioelectrochemistry 2018, 119, 76-83. [CrossRef] [PubMed]

58. Stirke, A.; Celiesiute-Germaniene, R.; Zimkus, A.; Zurauskiene, N.; Simonis, P.; Dervinis, A.; Ramanavicius, A.; Balevicius, $\mathrm{S}$. The link between yeast cell wall porosity and plasma membrane permeability after PEF treatment. Sci. Rep. 2019, 9, 1-10. [CrossRef]

59. Somolinos, M.; García, D.; Condón, S.; Mañas, P.; Pagán, R. Relationship between sublethal injury and inactivation of yeast cells by the combination of sorbic acid and pulsed electric fields. Appl. Environ. Microbiol. 2007, 73, 3814-3821. [CrossRef]

Publisher's Note: MDPI stays neutral with regard to jurisdictional claims in published maps and institutional affiliations. 